\title{
Kajian Minyak Serai Wangi (Cymbopogon nardus L.) terhadap Aedes aegypti
}

\section{Study of Citronella Oil (Cymbopogon nardus L.) on Aedes aegypti}

\author{
Yustin Nur Khoiriyah ${ }^{1}$, Nurminha ${ }^{2}$ \\ Jurusan Analis Kesehatan, Politeknik Kesehatan Tanjung Karang, Indonesia
}

\section{ARTICLE INFO}

\section{Article history}

Received date 18 Jun 2021

Revised date 22 Aug 2021

Accepted date 23 Aug 2021

\section{Keywords:}

Aedes aegypti; Citronella grass; Essential oil; Resistance.

Kata kunci:

Aedes aegypti; Serai wangi; Minyak atsiri,; Resistensi.

\begin{abstract}
ABSTRAK
The Aedes aegypti mosquito can develop an immune system against the insecticide used. Control efforts with the use of insecticides are no longer effective if the target insects have become resistant. So there needs to be an effort to overcome the insect resistance that is targeted. Citronella grass is an herbal plant that can be used as an ingredient in vegetable pesticides. The leaves and stems are distilled to produce essential oil known as citronella oil. This research is about studying the effects of citronella oil against the resistance of the vector carrier for dengue fever, namely Aedes aegypti. The detection of citronella essential oil (Cymbopogon nardus L.) by Thin Layer Chromatography showed a reduction in $\mathrm{UV}_{254}$ visualization ( $\left.\mathrm{Rf} 0,68\right)$. The resistance test showed that the mortality percentage of adult mosquitoes Aedes aegypti exposed to $0.03 \%$ alphacymethrin was $73,7 \%$ resistant criteria $(<90 \%)$. The mortality percentage of adult mosquitoes Aedes aegypti exposed to Alphacypermethrin (0,03\%) and citronella oil was 2,5\% each; $5 \%$; $7,5 \%$ and $10 \%$ with treatment time 15 respectively, namely $18,7 \%, 50,7 \%, 70,7 \%$ and $82,7 \%$; the treatment time of 30 minutes consecutively is $62,7 \%, 89,3 \%, 96 \%$ and $97,3 \%$ and the treatment time is 60 minutes respectively, namely $93,3 \%, 98,7 \%, 98,7 \%$ and $100 \%$. There was an increase in the percentage of mosquito deaths exposed to the combination of alphacypermethrin and citronella oil, compared to those without citronella oil, this indicates that mosquitoes are more susceptible and resistance has decreased due to exposure to citronella oil.
\end{abstract}

\begin{abstract}
Nyamuk Aedes aegypti mampu mengembangkan sistem kekebalan terhadap insektisida yang digunakan. Upaya penanggulangan dengan penggunaan insektisida tidak lagi efektif jika serangga yang menjadi sasaran telah resisten. Maka perlu adanya upaya guna mengatasi resistensi serangga yang menjadi sasaran. Serai wangi merupakan tanaman herbal yang dapat digunakan sebagai bahan pestisida nabati. Bagian daun dan batangnya disuling untuk menghasilkan minyak atsiri yang dikenal dengan minyak sitronela Penelitian ini tentang kajian efek serai wangi yang diperoleh terhadap resistensi vektor pembawa penyakit DBD yaitu Aedes aegypti. Hasil deteksi minyak atsiri sitronela pada minyak serai wangi (Cymbopogon nardus L.) dengan Kromatografi Lapis Tipis menunjukkan peredaman pada visualisasi $\mathrm{UV}_{254}$ ( $\left.\mathrm{Rf} 0,68\right)$. Uji resistensi diperoleh persentase kematian nyamuk dewasa Aedes aegypti yang dipapar alphacymethrin 0,03\% adalah $73,7 \%$ kriteria resisten $(<90 \%)$. Persentase kematian nyamuk dewasa Aedes aegypti yang dipapar kombinasi Alphacypermethrin 0,03\% dan minyak serai wangi masing-masing $2,5 \% ; 5 \% ; 7,5 \%$ dan $10 \%$ dengan perlakuan waktu 15 berturut-turut yaitu $18,7 \%, 50,7 \%, 70,7 \%$ dan $82,7 \%$; perlakuan waktu 30 menit berturut-turut yaitu $62,7 \%$, $89,3 \%, 96 \%$ dan $97,3 \%$ dan perlakukan waktu 60 menit berturut-turut yaitu 93,3\%, $98,7 \%, 98,7 \%$ dan $100 \%$. Terjadi peningkatan persentase kematian nyamuk yang dipapar oleh kombinasi alphacypermethrin dan minyak serai wangi, dibandingkan dengan tanpa minyak serai wangi, hal ini menunjukkan bahwa nyamuk lebih rentan dan resistensi mengalami penurunan akibat paparan minyak serai wangi.
\end{abstract}

Corresponding Author:

Yustin Nur Khoiriyah

Jurusan Analis Kesehatan, Politeknik Kesehatan Tanjung Karang, Indonesia

Email: yustinkhoiriyah@poltekkes-tjk.ac.id 


\section{PENDAHULUAN}

Demam berdarah dengue (DBD) dan sindrom syok dengue (DSS) telah menjadi masalah kesehatan masyarakat internasional. Selama tiga dekade terakhir, telah terjadi peningkatan global yang dramatis dalam frekuensi demam berdarah, DBD dan DSS dan epidemi mereka, dengan peningkatan yang bersamaan dalam kejadian penyakit. Demam berdarah ditemukan di daerah tropis dan subtropis di seluruh dunia, terutama di daerah perkotaan dan semi-perkotaan (WHO, 2011). DBD disebabkan oleh virus dari famili Flaviviradae yang disebarkan oleh nyamuk Aedes (Stegomyia). Tidak ada pengobatan khusus untuk demam berdarah, tetapi perawatan medis yang tepat sering menyelamatkan nyawa pasien dengan demam berdarah dengue yang serius. Cara paling efektif untuk mencegah penularan virus dengue adalah dengan memerangi nyamuk pembawa penyakit (WHO, 2011). Penggunaan insektisida merupakan salah satu upaya pengendalian nyamuk pembawa penyakit ini. Insektisida dapat mengendalikan serangga dengan menggangu atau merusak sistem dalam tubuh serangga, bentuknya berupa padatan, larutan atau gas. Umumnya saat ini digunakan 4 (empat) golongan yaitu organoklorin, organofosfat, karbonat dan piretroid. Cypermethrin merupakan salah satu golongan insektisida piretroid yang sering digunakan masyarakat untuk nyamuk Aedes karena harganya terjangkau (Kementerian Kesehatan RI, 2012).

Permasalahan baru muncul ketika terjadi resistensi serangga terhadap insektisida akibat paparan yang berlangsung lama. Nyamuk Aedes aegypti mampu mengembangkan sistem kekebalan terhadap insektisida yang digunakan. Serangga yang resisten akan bereproduksi dan perubahan genetik yang terjadi menurunkan keturunan resisten, sehingga meningkatkan proporsi vektor resisten di populasi (Kementerian Kesehatan RI, 2012).

Pradani, et al. (2011) mengatakan bahwa perlu adanya penentuan status kerentanan spesies nyamuk vektor secara berkala, guna monitoring terjadinya resistensi. Potensi resistensi yang diketahui lebih dini dapat digunakan untuk bahan pertimbangan strategi pengendalian vektor. Berdasarkan kajian yang dilakukan oleh (Widiarti, et al., 2011), resistensi nyamuk Aedes aegypti terhadap insektisida malathion $0,8 \%$, Bendiocarb 0,1\%, Landasihalotrin 0,05\%, permethrin $0,75 \%$, deltamethryin $0,05 \%$ dan Etofenproks $0,5 \%$ terjadi di Jawa Tengah dan daerah istimewa Yogyakarta. Resistensi terjadi juga di Kota Cimahi, Jawa Barat (Wahyudin, 2009) menguji kerentanan nyamuk Aedes aegypti terhadap beberapa insektisida, hasil diperoleh bahwa Aedes aegypti resisten terhadap insektisida golongan organofosfat dan toleran terhadap piretroid, serta resisten terhadap cypermethrin $0,2 \%$ dan $0,4 \%$ (Pradani, et al., 2011). Penelitian Nurminha \& Sulistianingsih, (2019) menunjukkan bahwa nyamuk Aedes aegypti yang berasal dari Kota Bandar Lampung di Wilayah PKM Way Kandis Resisten terhadap insektisida cypermethrin $0,03 \%$. Kematian nyamuk yang diberikan paparan cypermethrin $0,03 \%$ yaitu $4,5-18,3 \%$.

Serangga memiliki system enzimatis yang mampu menetralkan racun insektisida. Dua mekanisme nyamuk vektor DBD resisten terhadap insektisida, antara lain meningkatkan aktifitas enzim esterase dan ketidakpekaan pada acetylcholine esterase (AchE) (Widiarti, et al., 2011). Insektisida sintetik profenofos memiliki satu cara kerja yaitu mengganggu sistem saraf serangga dengan menghambar kerja enzim asetilkolinesterase (AChE) dan menyebabkan akumulasi asetilkolin (Untung, 2001; Djojosumarto, 2008).

Upaya penanggulangan dengan penggunaan insektisida tidak lagi efektif jika serangga yang menjadi sasaran telah resisten. Maka perlu adannya upaya guna mengatasi resistensi serangga yang menjadi sasaran, yaitu Aedes aegypti yang telah resisten dengan mengganggu sistem enzimatis.

Serai wangi merupakan tanaman herbal yang dapat digunakan sebagai bahan pestisida nabati. Bagian daun dan batangnya disuling untuk menghasilkan minyak atsiri yang dikenal dengan minyak sitronela. Masyarakat menggunakan minyak serai untuk pengusir nyamuk dan serangga lainnya, dengan cara digosok dikulit atau disemprot ke pakaian, penggunaan abu hasil pembakaran daun untuk mengendalikan hama gudang dan membakar daun serai untuk mengusir serangga, khususnya nyamuk (Puslitbang, 2012). Kiswanti (2009) telah melakukan uji efikasi produk gel penolak nyamuk terhadap 25 ekor nyamuk Culex quinquefasciatus, dengan hasil jumlah nyamuk yang jatuh setelah 6 jam dinyatakan mati pada konsentrasi serai wangi $10 \%, 15 \%$ dan $20 \%$, berturut-turut adalah 26,67\%, 52\% dan $60 \%$. (Wardani, 2009) mengkaji obat nyamuk elektrik berbahan aktif minyak serai wangi memiliki efektifitas terhadap Aedes aegypti dengan LC90 $25,63 \pm 2,3 \%$. Rondonuwu dan Langi (2006), menjelaskan bahwa konsentrasi minyak serai wangi $0,25 \%$ cukup membunuh larva nyamuk 
Aedes spp dan mencegah nyamuk bertelur. Wahyuningtyas (2004) menyatakan bahwa serai wangi pada konsentrasi 2,5\% dapat menolak nyamuk Aedes aegypti L. Mutchler (2010) menyatakan bahwa mekanisme kerja racun kontak sitronella adalah menghambat enzim asetilkolinesterase sehingga terjadi fosforilasi asam amino serin pada pusat aseterik enzim yang bersangkutan. Gejala keracunan pada serangga timbul karena adanya penimbunan asetikolin yang menyebabkan gangguan sistem saraf pusat, kejang, kelumpuhan pernafasan dan kematian. Berdasarkan hal itu, maka perlu dilakukan kajian efek serai wangi yang diperoleh dari proses destilasi terhadap resistensi vektor pembawa penyakit DBD yaitu Aedes aegypti. Tujuan penelitian ini adalah untuk mengetahui efek minyak serai wangi pada nyamuk Aedes aegypti betina dewasa yang sebelumnya telah diuji kerentanannya terhadap insektisida Alphacypermethrin 0,03\% dengan susceptibility test.

\section{METODE}

Jenis penelitian adalah penelitian eksperimental dengan rancangan post test only design (Notoatmodjo, 2010). Variabel yang diamati adalah konsentrasi dan lama waktu dari insektisida Alphacypermethrin dan minyak serai wangi (Cymbopogon nardus L.) hasil destilasi serta kematian dan kerentanan Aedes aegypti. Waktu penelitian dilaksanakan pada bulan MaretNovember Tahun 2020, lokasi penelitian dilaksanakan di Laboratorium Farmasi Poltekkes Tanjungkarang, Laboratorium Farmasi Universitas Malahayati, Balitbangkes Baturaja, Sumatera Selatan. Sampel yang digunakan dalam eksperimen ini adalah minyak serai wangi (Cymbopogon nardus L.). Minyak serai wangi diperoleh dari hasil ekstraksi dengan metode Destilasi. Nyamuk Aedes aegypti yang digunakan sebagai sampel adalah nyamuk Aedes aegypti keturunan 145 hasil kolonisasi di Laboratorium Entomologi Balitbangkes Baturaja, Sumatera Selatan. yang diuji resistensinya terhadap insektisida Alphacypermethrin 0,03\% (Nurminha \& Sulistianingsih, 2019). Sebagian dari populasi nyamuk yang dikembangbiakan menjadi sampel uji resistensi sebanyak 15 ekor tiap satuan pengamatan dan diambil secara acak (Pradani, et al., 2011). Telur nyamuk Aedes aegypti keturunan 145 dengan jumlah \pm 5000 ekor dikolonisasi sehingga diperoleh koloni nyamuk dewasa jantan dan betina. Hasil kolonisasi diperoleh \pm 1500 nyamuk dewasa betina. Sampel nyamuk dewasa yang seharusnya hasil kolonisasi larva nyamuk dari wilayah Way Kandis, situasi Pandemi Covid-19 menjadi alasan ketidaksediaan warga untuk diakses lingkungan dalam dan luar rumah warga. Sehingga ketersediaan larva nyamuk Aedes aegypti untuk kolonisasi tidak mencukupi jumlah nyamuk dewasa yang diperlukan dalam susceptibility test.

1. Deteksi minyak atsiri sitronela dengan Kromatografi Lapis Tipis

Minyak serai wangi hasil destilasi ditotolkan pada pelat $\mathrm{KLT} \mathrm{GF}_{254}$. Pemisahan komponen senyawa dengan menggunakan KLT memerlukan fase gerak toluene : etil asetat (8:1) (Astuti, 2012). Sebanyak 10mL fase gerak tersebut dimasukkan ke dalam bejana kromatografi dan dijenuhkan selama 20 menit. Setelah itu, pelat KLT yang telah berisi sampel dimasukkan ke dalam bejana kromatografi dan dipisahkan hingga fase gerak mencapai $\pm 0,5 \mathrm{~cm}$ dari tepi atas pelat. Selanjutnya pelat KLT diangkat, dikeringkan, dan dideteksi. Deteksi dilakukan untuk melihat pita yang muncul pada pelat KLT menggunakan sinar tampak dan $\mathrm{UV}_{254}$. Nilai Rf senyawa komponen minyak atsiri serai wangi (alfa-sitral, betasitral, kolumelarin, nerol asetat) $\pm 0,694$ (Astuti, 2012).

2. Proses rearing nyamuk Aedes aegypti

Telur Aedes aegypti F 145 dari Laboratorium Entomologi Balitbangkes Baturaja ditetaskan menjadi larva. Larva yang terkumpul dikembangbiakan/dikolonisasi dengan diberi pakan ekstrak hati sampai diperoleh nyamuk dewasa. Nyamuk dewasa generasi F145 digunakan dalam uji resistensi.

3. Pemeriksaan status resistensi nyamuk Aedes aegypti terhadap insektisida Alphacypermethrin 0,03\%

Uji resistensi dilakukan dengan metode susceptibility. Nyamuk yang digunakan adalah hasil kolonisasi dari lokasi penelitian dengan kondisi perut kenyang darah dengan alasan kondisinya sehat. Kemudian disiapkan tabung uji standar WHO dan pada tabung dengan tanda merah dimasukkan kertas berinsektisida Alphacypermethrin 0,03\%.

Tabung dengan tanda hijau dimasukkan kertas tanpa insektisida (PY control) sebagai kontrol. Setiap kelompok perlakuan memiliki 5 (lima) ulangan.

Nyamuk sebanyak 15 ekor dengan kondisi sehat dimasukkan dalam tabung uji, paparan selama 15, 30, 45 dan 60 menit (Pradani, et al., 2011). Setelah dipapar dengan insektisida, minyak serai dan pelarut selama 60 menit dalam tabung kontak dan dicatat jumlah nyamuk yang mengalami knockdown, nyamuk 
dipindahkan ke tabung kolektor dan ditempatkan dalam udara segar selama 24 jam (holding) dengan diberi makan larutan gula 5\% serta dijaga suhu dan kelembabannya, dengan ditutup handuk basah pada kotak tempat nyamuk diletakkan. Selain itu, dijauhkan pula dari jangkauan pemangsa nyamuk. Proporsi nyamuk mati setelah holding 24 jam dihitung.

Kriteria resistensi nyamuk ditentukan berdasarkan ketentuan WHO (2016), pengujian harus diulangi jika ada kematian pada kelompok kontrol lebih dari $20 \%$. Kematian nyamuk uji dikoreksi dengan formula Abbot jika kematian nyamuk pada kelompok kontrol kurang dari $20 \%$. Nilai rasio resistensi diperoleh dari hasil perhitungan persentase angka kematian nyamuk uji dengan perlakuan dan dibandingkan dengan nyamuk yang masih rentan (kontrol) (WHO, 2016).

4. Pembuatan larutan uji

a. Pembuatan pelarut tween $8015 \%$

Tween 80 sebanyak $15 \mathrm{~mL}$ dimasukkan dalam labu takar $100 \mathrm{~mL}$, kemudian ditambahkan aquades sampai batas dan dihomogenkan.

b. Pembuatan larutan uji

Formulasi larutan uji yang digunakan dalam uji resistensi dengan konsentrasi $2,5 \%, 5 \%, 7,5 \%, 10 \%$ dan $100 \%$

c. Pembuatan kertas uji Serai Wangi (Cymbopogon nardus L.)

Kertas saring dipotong dengan ukuran $12 \times 15 \mathrm{~cm}^{2}$ sesuai dengan ukuran kertas uji PY Control dan Alphacymetrin $0,03 \%$. Sedangkan ukuran kertas saring untuk kombinasi minyak serai wangi dan alphacymetrin $\quad 0,03 \%$ masing-masing kertas berukuran $6 \times 15 \mathrm{~cm}^{2}$. Kertas saring dengan bahan uji minyak serai wangi, dibasahi dengan larutan uji yang telah dibuat sesuai dengan formulasi larutan uji. Kertas saring dipres dan dikeringanginkan.

5. Pemeriksaan status kematian nyamuk dengan paparan kombinasi insektisida Alphacypermethrin $0,03 \%$ dan minyak serai wangi.

Uji ini untuk mengetahui jumlah kematian nyamuk akibat paparan insektisida dan minyak serai wangi dengan metode susceptibility. Tabung uji standar WHO disiapkan dengan ketentuan yaitu tabung dengan tanda merah dimasukkan kertas minyak serai $2,5 \%, 5 \%, 7,5 \%$ dan $10 \%$; dan kombinasi insektisida-minyak serai masing- masing 2,5\%, 5\%, 7,5\% dan $10 \%$, secara melingkar dengan susunan seperti Gambar 1. Tabung dengan tanda hijau dimasukkan kertas tanpa insektisida (pelarut tween 80 15\% dan PY control) sebagai kontrol. Setiap kelompok perlakuan memiliki 5 (lima) ulangan.

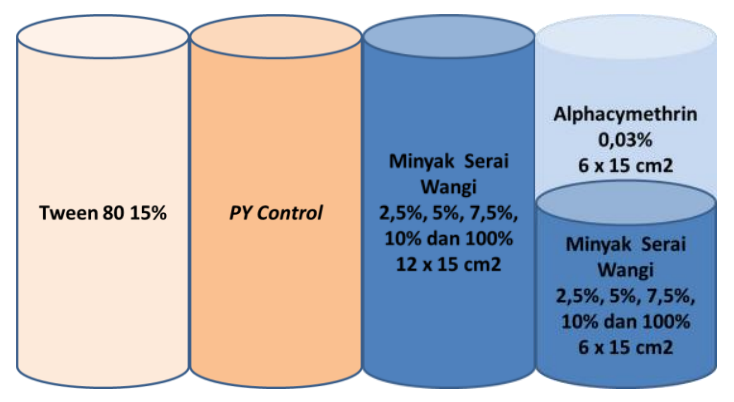

Gambar 1. Tabung uji kematian nyamuk Aedes aegypti

Nyamuk sebanyak 15 ekor dengan kondisi sehat dimasukkan dalam tabung uji, paparan selama 15, 30, 45 dan 60 menit. Setelah dipapar dengan insektisida, minyak serai dan pelarut selama 60 menit dalam tabung kontak dan dicatat jumlah nyamuk yang mengalami knockdown, nyamuk dipindahkan ke tabung kolektor dan ditempatkan dalam udara segar selama 24 jam (holding) dengan diberi makan larutan gula 5\% serta dijaga suhu dan kelembabannya, dengan ditutup handuk basah pada kotak tempat nyamuk diletakkan. Selain itu, dijauhkan pula dari jangkauan pemangsa nyamuk. Proporsi nyamuk mati setelah holding 24 jam dihitung. Analisis data univariat untuk menentukan persentase kematian nyamuk Aedes aegypti.

\section{HASIL}

Hasil visualisasi Kromatografi Lapis Tipis (KLT) dengan $\mathrm{UV}_{254}$, terdapat 2 (dua) pita/ titik peredaman dengan nilai Rf 0,55 dan 0,68.

Uji kerentanan nyamuk Aedes aegypti F145 betina dewasa dilakukan dengan memberikan paparan insektisida Alphacypermethrin 0,03\% selama 60 menit. Nyamuk yang mengalami knockdown selama paparan dapat dilihat pada tabel 1 berikut. 
Tabel 1.Persentase Nyamuk Aedes aegypti yang Mengalami Knockdown pada Pengamatan 15, 30, 60 menit dengan Paparan Insektisida Alphacypermethrin 0,03\%

\begin{tabular}{lrrr}
\hline \multirow{2}{*}{ Jenis Paparan } & \multicolumn{3}{c}{ \%Knockdown } \\
\cline { 2 - 4 } & $\begin{array}{c}\mathbf{1 5} \\
\text { menit }\end{array}$ & $\begin{array}{c}\mathbf{3 0} \\
\text { menit }\end{array}$ & $\begin{array}{c}\mathbf{6 0} \\
\text { menit }\end{array}$ \\
\hline PY Control & 0 & 0 & 0 \\
Alphacymetrin $0,03 \%$ & 0 & 17,3 & 50,7 \\
\hline
\end{tabular}

Tabel 2.Persentase Kematian Nyamuk Aedes aegypti pada Pengamatan 24 jam dengan Paparan Insektisida Alphacypermethrin 0,03\%

\begin{tabular}{lr}
\hline \multicolumn{1}{c}{ Jenis Paparan } & \% Kematian \\
\hline PY Control & 4 \\
Alphacymetrin $0,03 \%$ & 74,7 \\
\hline
\end{tabular}

Tabel 2 menunjukkan persentase kematian $<20 \%$ pada pengamatan 24 jam sehingga uji tidak perlu diulang. Berdasarkan Tabel 2 di atas maka dilakukan penghitungan resistensi Nyamuk Aedes aegypti terhadap Alphacymethrin 0,03\% dengan menggunakan Formula dari ABBOTS. Hasil hitungan menunjukan \%Abbots sebesar 73,7 (resisten).

Sedangkan nyamuk yang mengalami knockdown selama paparan minyak serai serta kombinasi Alphacypermethrin 0,03\%-minyak serai selama 60 menit dapat dilihat pada tabel 3 .

Tabel 3.Persentase Nyamuk Aedes aegypti $\mathrm{F}_{145}$ Betina Dewasa yang Mengalami Knockdown pada Pengamatan 15, 30, 60 menit dan Kematian pada Pengamatan 24 jam

\begin{tabular}{|c|c|c|c|}
\hline \multirow[b]{2}{*}{ Jenis Paparan } & \multicolumn{3}{|c|}{ \%Knockdown } \\
\hline & $\begin{array}{c}15 \\
\text { menit }\end{array}$ & $\begin{array}{c}30 \\
\text { menit }\end{array}$ & $\begin{array}{c}60 \\
\text { menit }\end{array}$ \\
\hline Minyak Serai $100 \%$ & 98,7 & 98,7 & 100 \\
\hline Minyak Serai $10 \%$ & 100 & 100 & 100 \\
\hline Minyak Serai 7,5\% & 89,3 & 98,7 & 100 \\
\hline Minyak Serai 5\% & 68 & 94,7 & 98,7 \\
\hline Minyak Serai $2,5 \%$ & 42,7 & 58,7 & 82,7 \\
\hline $\begin{array}{l}\text { Minyak Serai } 100 \%+ \\
\text { Alphacymetrin } 0,03 \%\end{array}$ & 77,3 & 94,7 & 100 \\
\hline $\begin{array}{l}\text { Minyak Serai } 10 \%+ \\
\text { Alphacymetrin } 0,03 \%\end{array}$ & 82,7 & 97,3 & 100 \\
\hline $\begin{array}{l}\text { Minyak Serai } 7,5 \%+ \\
\text { Alphacymetrin } 0,03 \%\end{array}$ & 70,7 & 96 & 98,7 \\
\hline $\begin{array}{l}\text { Minyak Serai } 5 \%+ \\
\text { Alphacymetrin } 0,03 \%\end{array}$ & 50,7 & 89,3 & 98,7 \\
\hline $\begin{array}{l}\text { Minyak Serai } 2,5 \%+ \\
\text { Alphacymetrin } 0,03 \%\end{array}$ & 18,7 & 62,7 & 93,3 \\
\hline
\end{tabular}

Semakin tinggi konsentrasi larutan uji minyak serai maka semakin tinggi persentase nyamuk dewasa yang mengalami knockdown pada pengamatan 15,30 dan 60 menit.

Setelah 60 menit paparan, nyamuk dipindahkan dalam tabung holding yang bebas dari paparan dengan ditempatkan dalam udara segar selama 24 jam (holding) untuk diamati kematian nyamuk (Tabel 4).

Tabel 4. Persentase Kematian Nyamuk Aedes aegypti pada Pengamatan 24 jam dengan Paparan Minyak Serai Wangi dan Kombinasi Alphacymetrin 0,03\%-Minyak Serai Wangi

\begin{tabular}{lr}
\multicolumn{1}{c}{ Jenis Paparan } & \% Kematian \\
\hline Minyak Serai 100\% & 100 \\
Minyak Serai 10\% & 100 \\
Minyak Serai 7,5\% & 89,3 \\
Minyak Serai 5\% & 90,7 \\
Minyak Serai 2,5\% & 69,3 \\
\hline Minyak Serai 100\%+ & 100 \\
Alphacymetrin 0,03\% & \\
Minyak Serai 10\%+ & 100 \\
Alphacymetrin 0,03\% & \\
Minyak Serai 7,5\%+ & 92 \\
Alphacymetrin 0,03\% & \\
Minyak Serai 5\%+ & \\
Alphacymetrin 0,03\% & 97,3 \\
Minyak Serai 2,5\%+ & \\
Alphacymetrin 0,03\% & 73,3 \\
\hline
\end{tabular}

Persentase kematian akibat paparan minyak serai wangi konsentrasi $>2,5 \%$ lebih tinggi dari persentase kematian nyamuk yang terpapar alphacypermethrin $0,03 \%$. Persentase kematian akibat paparan kombinasi minyak serai wangi konsentrasi $>2,5 \%$ dan alphacypermethrin lebih tinggi dari persentase kematian nyamuk yang terpapar alphacypermethrin $0,03 \%$ atau minyak serai wangi saja pada pengamatan 24 jam. Kematian $100 \%$ nyamuk dewasa terjadi pada kelompok paparan minyak serai wangi $10 \%$ dan $100 \%$, serta kombinasi minyak serai wangi $10 \%$ dan $100 \%$ dengan alphacepermethrin $0,03 \%$.

\section{PEMBAHASAN}

Sampel serai wangi (Cymbopogon nardus L.) diperoleh dari kebun warga Natar, Lampung Selatan sebelum didestilasi untuk memperoleh minyak serai wangi daun salam, diperlakukan dengan serangkaian proses, dimulai dari penyortiran, pencucian, pengeringan, dan perajangan. Daun dan batang segar disortir untuk memisahkan kotoran, kerikil, serangga dan bahan asing (tanaman selain serai wangi) guna mengurangi jumlah pengotor pada sampel utama. Pencucian bertujuan menghilangkan debu dan mikroba yang melekat pada daun dan batang segar. Pengeringan dilakukan dibawah sinar matahari tidak langsung, ditempat ternaungi dan ditutup dengan kain hitam. Daun yang kering dirajang/diserbuk untuk memperluas permukaan partikel yang berinteraksi dengan pelarut organik, sehingga proses destilasi dapat efektif dan efisien. 
Hasil destilasi serai wangi dengan berat $25 \mathrm{gr}$ diperoleh minyak atsiri sebanyak $0,2 \mathrm{~mL}$ atau $0,17 \mathrm{gr}$, sehingga rendemen diperoleh $0,69 \%$. Rendemen merupakan perbandingan antara berat ekstrak yang dihasilkan dengan berat simplisia. Semakin besar persentase rendemen yang dihasilkan maka semakin efektif proses ekstraksi, karena semakin banyak kandungan golongan besar senyawa terlarut dalam pelarut yang digunakan dalam proses ekstraksi. Minyak serai wangi hasil destilasi dilakukan deteksi adanya minyak atsiri sitronela dengan Kromatografi Lapis Tipis (KLT).

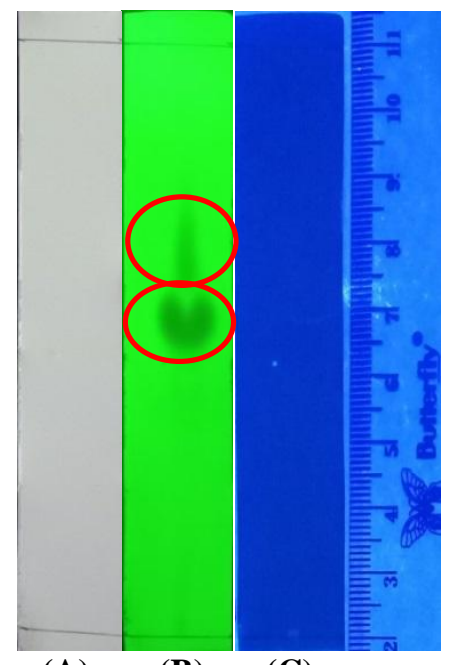
(A)
(B)
(C)

Gambar 2. Kromatogram hasil KLT minyak Serai Fase diam : silica gel GF254 Wangi (Cymbopogon nardus L.)

Fase gerak : $\mathrm{CH} 4 \mathrm{O}: \mathrm{CHCl} 3: \mathrm{CH} 2 \mathrm{Cl} 2$ 1:3:6 (v/v/v)

Keterangan : (A) Visibel/ Sinar tampak, (B) UV254, dan (C) UV366

Gambar 2 menunjukkan hasil visualisasi KLT dengan UV254, terdapat 2 (dua) pita/ titik peredaman dengan nilai Rf 0,55 dan 0,68 . Hal ini menunjukkan bahwa hasil destilasi memiliki komponen minyak sitronela. Hal ini sejalan dengan penelitian Astuti (2012), minyak atsiri pada serai wangi dikenal dengan minyak sitronela dimana komponennya terdiri dari alfasitral, betasitral, kolumelarin, nerol asetat. Deteksi dilakukan untuk melihat pita yang muncul pada pelat KLT menggunakan sinar UV254. Nilai Rf senyawa komponen minyak atsiri serai wangi (alfa-sitral, betasitral, kolumelarin, nerol asetat) $\pm 0,694$.

Minyak serai wangi (Cymbopogon nardus L.) sebagai bahan uji untuk memberikan efek sinergis dengan insektisida alphacymethrin $0,03 \%$ sehingga persentase kematian nyamuk meningkat. Kematian nyamuk dihitung pada pengamatan 24 jam, dimana nyamuk telah dipindahkan pada tabung holding dan ditempatkan dalam udara segar setelah 60 menit paparan insektisida dan serai wangi. Nyamuk yang knockdown dapat memulihkan kondisi kembali atau mengalami kematian. Berdasarkan hasil yang ditunjukkan pada tabel 2 dan 4, terjadi peningkatan persentase kematian nyamuk yang dipapar oleh kombinasi alphacypermethrin dan minyak serai wangi, dibandingkan dengan tanpa minyak serai wangi. Persentase kematian akibat paparan minyak serai wangi konsentrasi $>2,5 \%$ lebih tinggi dari persentase kematian nyamuk yang terpapar alphacypermethrin 0,03\%. Persentase kematian akibat paparan kombinasi minyak serai wangi konsentrasi $>2,5 \%$ dan alphacypermethrin lebih tinggi dari persentase kematian nyamuk yang terpapar alphacypermethrin $0,03 \%$ atau minyak serai wangi saja pada pengamatan 24 jam. Kematian $100 \%$ nyamuk dewasa terjadi pada kelompok paparan minyak serai wangi $10 \%$ dan $100 \%$, serta kombinasi minyak serai wangi $10 \%$ dan $100 \%$ dengan alphacypermethrin $0,03 \%$.

Tabel 2 juga menunjukkan persentase kematian $<20 \%$ pada pengamatan 24 jam sehingga uji tidak perlu diulang. Semakin tinggi konsentrasi larutan uji minyak serai maka semakin tinggi persentase nyamuk dewasa yang mengalami knockdown pada pengamatan 15, 30 dan 60 menit (Tabel 3).

Mekanisme kerja racun kontak sitronella adalah menghambat enzim asetilkolinesterase sehingga terjadi fosforilasi asam amino serin pada pusat aseterik enzim yang bersangkutan (Mutchler, 2010). Seperti mekanisme kerja insektisida sintetik profenofos, yaitu mengganggu sistem saraf serangga dengan menghambat kerja enzim asetilkolinesterase (AChE) dan menyebabkan akumulasi asetilkolin (Untung, 2001; Djojosumarto, 2008). Serai wangi merupakan tanaman herbal yang dapat digunakan sebagai bahan pestisida nabati. Bagian daun dan batangnya disuling untuk menghasilkan minyak atsiri yang dikenal dengan minyak sitronela (Puslitbang, 2012).

Sampel yang digunakan pada uji resistensi adalah hasil penetasan sediaan telur Aedes aegypti $\mathrm{F} 145$ dari Laboratorium Entomologi Balitbangkes Baturaja. Telur menetas menjadi larva, larva yang terkumpul dikembangbiakan/ dikolonisasi dengan diberi pakan ekstrak hati sampai diperoleh nyamuk dewasa. Nyamuk dewasa generasi F145 digunakan dalam uji resistensi. Nyamuk tidak diambil dari Way Kandis, karena kondisi pandemi Covid-19 sehingga saat perijinan mengambil jentik terkendala ijin pemilik rumah warga. Nyamuk dewasa Aedes aegypti F145 dari Laboratorium Entomologi Balitbangkes Baturaja setelah diuji 
resistensi dengan alphacypermethrin $0,03 \%$ menunjukkan kematian $<90 \%$ pada pengamatan 24 jam, berdasarkan WHO (2016) menjelaskan kriteria uji resistensi kategori resisten jika kematian $<90 \%$.

\section{DAFTAR PUSTAKA}

Astuti, E. P. (2012). Pemisahan Sitral Dari Minyak Atsiri Serai Dapur ( Cymbopogon citratus ) Sebagai Pelangsing Aromaterapi. [Skripsi]. Bogor: Institut Pertanian Bogor.

Djojosumarto, P. (2008). Pestisida dan Aplikasinya. Jakarta: Agromedia Pustaka.

Kiswanti, D.E. (2009). Pemanfaatan Karagenan yang Ditambahkan Minyak Sereh Wangi pada Formula Gel Penolak Nyamuk Culex quinguefasciatus. [Skripsi]. Bogor: Program Sarjana, Institut Pertanian Bogor.

Kementerian Kesehatan RI. (2012). Pencegahan dan Pemberantasan Demam Berdarah Dengue (Buku ke 2). Kemenkes RI.

Mutchler, E. (2010). Dinamika Obat: Buku Ajar Farmakologi dan Toksikologi. Edisi 5. Diterjemahkan oleh Widianto, $M$ dan A.S. Kanti. ITB. Bandung.

Nurminha, \& Sulistianingsih, E. (2019). Pola resistensi Nyamuk Aedes aegypti Terhadap Insektisida Alphacypermethrin di Daerah Endemis DBD Provinsi Lampung Tahun 2019. Laporan Hasil Penelitian Politeknik Kesehatan Tanjungkarang.

Notoatmodjo, S. (2010). Metodologi Penelitian Kesehatan. Jakarta: Rineka Cipta

Pradani, Y., Mara, I., Rina, M., \& Yuneu, Y. (2011). Status Resistensi Aedes aegypti dengan Metode Susceptibility di Kota Cimahi terhadap Cypermethrin. Jurnal Aspirator, 3(1), 18-24.

Puslitbang. (2012). Fungsi pestisida nabati (Cetakan II, Issue April). Pusat Penelitian dan Pengembangan Perkebunan, Badan Penelitian dan Pengembangan Pertanian, Kementerian Pertanian.

Rondonuwu S.J., Langi, Y.A.R. (2006). Minyak sereh dalam pengendalian populasi Aedes spp. Eugenia 12 (3): 258-261. http://www.nri.orgprojectsadapptdocs6384pdf.

\section{SIMPULAN}

Persentase kematian nyamuk dewasa Aedes aegypti yang dipapar alphacymethrin $0,03 \%$ adalah $73,7 \%$ kriteria resisten $(<90 \%)$. Ada peningkatan persentase kematian nyamuk yang dipapar oleh kombinasi alphacypermethrin $0,03 \%$ dan minyak serai wangi konsentrasi $>2,5 \%$ dibandingkan dengan tanpa minyak serai wangi. Hal ini menunjukkan bahwa nyamuk lebih rentan dan resistensi mengalami penurunan akibat paparan minyak serai wangi.

Untung, K. (2001). Pengantar Pengelolaan Hama Terpadu. Yogyakarta: Gadjah Mada University Press.

Wahyudin, D. (2009). Uji Kerentanan Nyamuk Vektor Aedes aegypti Terhadap Insektisida yang Digunakan dalam Program Pengendalian Demam Berdarah Dengue (DBD) di Kota Cimahi Provinsi Jawa Barat. [Tesis]. Yogyakarta: Universitas Gadjah Mada.

Wahyuningtyas, E. (2004). Studi Daya Proteksi Serai Wangi (Cymbogopogon nardus (L.) Rendle) sebagai repelen terhadap nyamuk Aedes aegypti Linnaeus. [Skripsi]. Bogor: Program Sarjana, Institut Pertanian Bogor.

Wardani, S. (2009). Uji Aktivitas Minyak Atsiri Daun Dan Batang Serai (Andropogon Nardus L ) Sebagai Obat Nyamuk Elektrik Terhadap Nyamuk Aedes Aegypti. [Skripsi]. Surakarta: Universitas Muhammadiyah Surakarta.

WHO. (2011). Comprehensive guidelines for prevention and control of dengue and dengue haemorrhagic fever. WHO Regional Publication SEARO (Issue 1). https://doi.org/10.1017/CBO97811074153 24.004

WHO. (2016). Monitoring and managing insecticide resistance in Aedes mosquito populations: Interim guidance for entomologists. Geneva: WHO Press. https://apps.who.int/iris/bitstream/handle/106 65/204588/WHO_ZIKV_VC_16.1_eng.pdf.

Widiarti, Heriyanto, B., Boewono, D., Mujioni, Lasmiati, \& Yuliadi. (2011). Peta resistensi vektor demam berdarah dengue Aedes aegypti terhadap insektisida kelompok organofosfat, karbamat dan piretroid di Provinsi Jawa Tengah dan Daerah Istimewa Yogyakarta. Buletin Penelitian Kesehatan, 39(4), 176-189. 